\title{
Identification of Phytophthora cryptogea as the Cause of Rapid Decline of Petunia (Petunia $\times$ hybrida) in Chile
}

\author{
J. Ampuero, B. A. Latorre, and R. Torres, Facultad de Agronomía e Ingeniería Forestal, Pontificia Universidad \\ Católica de Chile, Casilla 306-22, Santiago Chile; and E. R. Chávez, Departamento Laboratorios y Estaciones \\ Cuarentenarias, Servicio Agrícola y Ganadero de Chile, SAG, Casilla 4088, Santiago Chile
}

\begin{abstract}
Ampuero, J., Latorre, B. A., Torres, R., and Chávez, E. R. 2008. Identification of Phytophthora cryptogea as the cause of rapid decline of petunia (Petunia $\times$ hybrida) in Chile. Plant Dis. 92:1529-1536.

Phytophthora cryptogea was consistently isolated from diseased tissue taken from the crown and necrotic roots of grandiflora type petunia (Petunia $\times$ hybrida) that were collected in gardens in five public parks in Santiago, Chile in 2004 and 2005. Symptoms included leaf wilting and foliar chlorosis, followed by partial necrosis, and extensive dark-brown to reddish cankers in the crown. Disease incidence was over 50\% and infected plants died within 7 to 10 days after transplanting. This pathogen was identified on the basis of colony morphology, morphological characterization of the sexual and asexual reproductive structures, and temperature range. The identification of Phytophthora cryptogea was further corroborated by the internal transcribed spacer sequence analysis (GenBank accession number EF093534). Isolates of P. cryptogea were pathogenic on 10-week-old white grandiflora petunia plants that were inoculated on the roots or on the crown using mycelium fragments, or via soil inoculation using zoospores. A rapid decline was observed after soil inoculations with zoospores. Root fresh weight decreased significantly and the root rot index and severity of foliage symptoms increased significantly $(P \leq 0.05)$, relative to noninoculated plants after 14 days of incubation. Two isolates $(\mathrm{Ph}-1$ and $\mathrm{Ph}-2)$ were pathogenic on bell pepper and one isolate $(\mathrm{Ph}-1)$ was pathogenic on tomato after root inoculation. Two isolates ( $\mathrm{Ph}-2$ and $\mathrm{Ph}-3)$ were pathogenic on the fruit of avocado, bell pepper, cherry tomato, cucumber, kiwifruit, lemon, pear, pepino, and potato tubers, demonstrating the pathogen's ability to cause postharvest infection of fruit of a wide range of host plants. The efficacy of mefenoxam at $0.1 \mathrm{mg} / \mathrm{ml}$ mixed with either chlorothalonil at $1.0 \mathrm{mg} / \mathrm{ml}$ or mancozeb at 1.6 $\mathrm{mg} / \mathrm{ml}$ was demonstrated in this study, whereas chlorothalonil and mancozeb alone did not control disease development. No significant differences were obtained between foliage and soil drench applications. This study demonstrated that P. cryptogea is the cause of the rapid decline found on petunia in Santiago, Chile and, to our knowledge, this is the first report giving a detailed description of a disease caused by $P$. cryptogea on petunia.
\end{abstract}

Additional keywords: fungicides, oomycetes

In recent years, a blight of petunia (Petunia $\times$ hybrida Hort. Vilm.-Andr.) has occurred 7 to 10 days after transplant in the city of Santiago, Chile. This has impeded the establishment and performance of petunia, a solanaceous species important as an ornamental and widely planted in public and private parks in Santiago. Losses of higher than $50 \%$ of the plants were commonly observed in public gardens. Diseased plants developed a general wilting, chlorosis, leaf necrosis, a light-brown to reddish canker at the crown, and partial to complete root rot. Infected plants failed to grow and eventually died before blooming.

It was postulated that this disease, called

Corresponding author: B. A. Latorre

E-mail: blatorre@uc.cl

Accepted for publication 16 July 2008.

doi:10.1094/PDIS-92-11-1529

(c) 2008 The American Phytopathological Society in three districts of Santiago (Providencia, Las Condes, and Lo Barnechea) during the spring 2004 and 2005. Plant samples were washed under running tap water to dislodge soil from roots. Small segments (5 to $10 \mathrm{~mm}$ long) of crown and root tissues were selected at the margins of diseased tissue. Each segment was surface disinfested for 1 to $2 \mathrm{~s}$ with $75 \%$ ethanol, blotted, and immediately placed in petri plates containing either acidified potato dextrose agar (APDA; $0.2 \mathrm{ml}$ of $92 \%$ lactic acid per liter of PDA) or corn meal agar modified with $150 \mathrm{mg}$ of ampicillin (Laboratorio Chile, S.A. Santiago, Chile), $10 \mathrm{mg}$ of pimaricin (Delvocid, Gist-brocades, Holland), $16 \mathrm{mg}$ of rifampicin (Laboratorio Chile, Santiago, Chile), $10 \mathrm{mg}$ of benomyl (Benlate, E. I. du Pont de Nemours and Co., Wilmington, DE), $100 \mathrm{mg}$ of pentachloronitrobenzene (Brassicol, Syngenta) and $30 \mathrm{mg}$ of hymexazol (Tachigaren, Sankio, Japan) (PARPH) (13) per liter Fungicides and antibiotics were added after autoclaving. Cultures were incubated in darkness at $20^{\circ} \mathrm{C}$ for 7 days.

Growth characteristics of mycelium on agar media were examined using a light microscope; the presence of hyaline, coenocytic hyphae, and right-angle branching is typical of some species of Phytophthora (8). Hyphal tips from emerging Phytophthora colonies were subcultured on PARPH. Of 40 isolates believed to be Phytophthora spp. recovered from individual plants, 5 were selected for further characterization.

Morphological characterization. Phytophthora isolates were identified to species based on morphological, physiological, and molecular characteristics $(5,8$, 26,28 ). Colony morphology was characterized after 5 to 7 days at 20 to $22^{\circ} \mathrm{C}$ on clarified V8 juice agar (V8; $250 \mathrm{ml}$ of clarified V8 juice, $15 \mathrm{~g}$ of agar, and $750 \mathrm{ml}$ of distilled water). V8 was clarified by adding $14 \mathrm{~g}$ of $\mathrm{CaCO}_{3}$ per liter of $\mathrm{V} 8$ juice and centrifuging at $2,500 \times g$ for $20 \mathrm{~min}$. The effect of temperature $(5,10,15,20$, 25,30 , and $35^{\circ} \mathrm{C}$ ) on the growth of mycelium was studied on PARPH. Each isolate was plated in triplicate and colony diameter was determined after 7 days of incubation.

Sporangia production was induced by placing agar plugs of each isolate in $9-\mathrm{cm}$ glass petri plates containing carrot juice broth (CJB), then incubating them for 48 
to $72 \mathrm{~h}$ at 20 to $22^{\circ} \mathrm{C}$ and continuous fluorescent light. The CJB was prepared with $500 \mathrm{~g}$ of fresh chopped carrot boiled in a liter of distilled water for $15 \mathrm{~min}$, then decanted and autoclaved. To stimulate sporangia production, mycelium was washed in sterile distilled water and incubated in $1.5 \%(\mathrm{wt} / \mathrm{vol})$ nonsterile soil extract solution (19). Development of sporangia was assessed by direct observation under a light microscope. Sporangial shape, size, length:breadth ratio, presence or absence of papilla, internal proliferation, and branching of sporangiophores were determined for at least 50 individuals per each of five isolates.

Gametangia production was studied on clarified V8 juice agar amended (AV8) with $30 \mathrm{mg}$ of $\beta$-sitosterol, $20 \mathrm{mg}$ of tryptophan, $1 \mathrm{mg}$ of thiamine- $\mathrm{HCl}$, and $100 \mathrm{mg}$ of $\mathrm{CaCl}_{2}$ per liter. Each isolate was plated in triplicate as a single culture or paired with $P$. cinnamomi A1 or A2 compatibility types (Cornell University, Geneva, NY). Cultures were incubated in the dark for 20 to 30 days at $20^{\circ} \mathrm{C}$. The stimulatory effect of sexual hormones was also studied. Each isolate was plated on 45-mm-diameter petri plates containing AV8 and incubated at $20^{\circ} \mathrm{C}$ for 5 days in the dark. A sterile nitrocellulose membrane $(45 \mathrm{~mm}$ in diameter, with $0.2-\mu \mathrm{m}$ pore diameter) was placed in direct contact with the mycelium, and an AV8 agar plug (5 $\mathrm{mm}$ in diameter) culture of the A1 and A2 compatibility type of $P$. cinnamomi was placed on the upper side of the membrane. Oospore production was determined using a light microscope. This experiment was repeated with isolates of P. cryptogea on the upper side of the membrane to induce oospore production by A1 or A2 compatibility types of $P$. cinnamomi below. These cultures were further incubated at $20^{\circ} \mathrm{C}$ for 20 days in the dark. The presence of oogonia, antheridia, and oospores were scored by direct examination under a light microscope. Oospore diameter was measured for at least 50 oospores per isolate (14).

DNA extraction, polymerase chain reaction amplification, and sequence analysis. Two of our isolates (Ph-3 and $\mathrm{Ph}-5)$ were selected for DNA sequence analysis. Total genomic DNA was extracted from $100 \mathrm{mg}$ of mycelium obtained from 7-day-old PARPH cultures grown at $20^{\circ} \mathrm{C}$. The mycelium was ground in a mortar with $1 \mathrm{ml}$ of lysis buffer (1 M Tris HCL, pH 7.5, $5 \mathrm{M} \mathrm{NaCl}, 0.5 \mathrm{M}$ EDTA, and $10 \%$ sodium dodecyl sulfate). This mixture was incubated at $65^{\circ} \mathrm{C}$ for $60 \mathrm{~min}$ before centrifugation $(2,800 \times g, 5 \mathrm{~min})$. The supernatant was mixed in Eppendorf tubes with an equal volume of cold $\left(-20^{\circ} \mathrm{C}\right)$ isopropanol and then incubated at room temperature for $15 \mathrm{~min}$. The precipitated DNA was separated by centrifugation $(2,800 \times g, 5 \mathrm{~min})$, washed in $70 \%$ ethanol, and recentrifuged $(2,800 \times g, 2 \mathrm{~min})$. The pellets were collected and dried at $37^{\circ} \mathrm{C}$ for $30 \mathrm{~min}$ before resuspending in $100 \mu \mathrm{l}$ of double-distilled water free of DNase and RNase. The internal transcribed spacer (ITS) region of the ribosomal DNA was amplified in a PTC 150 Hot Bonnet thermocycler (MJ Research Inc., NV) using the primers ITS4 and ITS6 (5). Each 25- $\mu$ l polymerase chain reaction (PCR) mixture contained $1 \mu \mathrm{l}$ of template (DNA at 1 to 2 $\mathrm{ng} / \mu \mathrm{l}), 0.2 \mu \mathrm{M}$ ITS4 and ITS6, 1 unit of Taq DNA polymerase (Invitrogen, Brazil), 1× PCR Buffer (Invitrogen, Brazil), 1.5 $\mathrm{mM} \mathrm{MgCl}_{2}, 0.25 \mathrm{mM}$ each deoxyribonucleotide (dNTP), $2.5 \mu \mathrm{l}$ of bovine serum albumin (BSA; $10 \mathrm{mg} / \mathrm{ml}$; Promega), and double-distilled water. The reaction cycle consisted of $3 \mathrm{~min}$ at $93^{\circ} \mathrm{C}$; followed by 35 cycles of $30 \mathrm{~s}$ at $55^{\circ} \mathrm{C}, 60 \mathrm{~s}$ at $72^{\circ} \mathrm{C}$, and $30 \mathrm{~s}$ at $94^{\circ} \mathrm{C}$; with a final extension period at $72^{\circ} \mathrm{C}$ for $10 \mathrm{~min}$. The amplified products $(10 \mu \mathrm{l})$ were digested using $0.5 \mu \mathrm{l}$ of the restriction enzymes $A l u \mathrm{I}$ or MspI (5 units/ $\mu$; Promega), $2 \mu \mathrm{l}$ of buffer $(1 \times)$, and $7 \mu \mathrm{l}$ of sterile double-distilled water at $37^{\circ} \mathrm{C}$ for $16 \mathrm{~h}$. The digested fragments were separated by electrophoresis on a $2.5 \%$ agarose gel (low-melting-point agarose; Bio-Rad Laboratories, CA) in $1 \times$ Tris-acetate-EDTA buffer (Invitrogen, USA). Bands were visualized with ethidium bromide under UV light (UVP Transilluminator, $302 \mathrm{~nm}$, UK). In each test, $P$. capsici, $P$. inundata, and $P$. fragariae var. fragariae were included as positive controls and water was used as negative control. A standard 100-bp molecular weight DNA marker (Fermentas, USA) was always included. The Phytophthora spp. were identified by Phytid CABI Bioscience (www.phytid.org/identify. asp).

The identification of isolate $\mathrm{Ph}-3$ was confirmed molecularly at CABI Bioscience UK (Centre-Egham, England) using the ITS region of the rDNA, and sequence data obtained were aligned and compared with known sequences of $P$. cryptogea isolates.

Pathogenicity tests. Five representative isolates of Phytophthora obtained from affected petunia plants were tested for pathogenicity on 10-week-old, white grandiflora petunia (Petunia $\times$ hybrida, $\mathrm{cv}$. Bravo F1 White) obtained from a local nursery. The petunia plants were grown and maintained in 500-ml containers.

Twenty plants were inoculated either at the crown or in the roots. The crowns of 10 plants were inoculated by inserting a 3mm-diameter mycelial plug, cut from 7day-old Phytophthora colonies growing on PARPH, underneath the epidermis of each plant. Wounds were immediately wrapped with Parafilm to reduce dehydration. An equal number of injured but noninoculated plants and noninjured noninoculated plants were used as controls.

The roots of 10 plants were inoculated with a mycelial suspension of $25 \mathrm{ml} /$ plant prepared from 7-day-old cultures that were grown in $\mathrm{CJB}$, macerated with distilled water, and adjusted to $10^{6} / \mathrm{ml}$ using a hemacytometer. The inoculum was added to a 6-cm-deep hole made near the crown of each plant and soil was kept saturated with water for $24 \mathrm{~h}$. An equal number of flooded, injured, noninoculated, and flooded, noninjured, noninoculated plants served as controls. Additionally nonflooded, noninjured, noninoculated plants were also used as control plants. All plants were incubated in a screenhouse where maximum air temperatures ranged from 21 to $30^{\circ} \mathrm{C}$ and minimum temperatures ranged from 10 to $12^{\circ} \mathrm{C}$.

After 7 days, the disease severity of the aerial and root symptoms was visually estimated for each plant on a 0 -to-5 scale. For aerial symptoms, $0=$ healthy plants and $1,2,3,4$, and 5 were $<20,21$ to 40,41 to 60,61 to 80 , and $>80 \%$ of the foliage showing symptoms, respectively. For root rot, $0=$ all healthy roots and $1,2,3,4$, and 5 were $<20,21$ to 40,41 to 60,61 to 80 , and $>80 \%$ rotted roots, respectively. The fresh foliage weight and fresh and dried root $\left(60^{\circ} \mathrm{C} ; 24 \mathrm{~h}\right)$ weights were determined for each plant.

Additional tests were conducted using zoospores from isolates $\mathrm{Ph}-3$ and $\mathrm{Ph}-4$; these isolates were highly and slightly virulent, respectively, in the previous pathogenicity experiment. Zoospores were produced on $10 \%$ V8 juice agar $(0.2 \%$ $\mathrm{CaCO}_{3}, 10 \mathrm{ml}$ of $\mathrm{V} 8$ juice, $90 \mathrm{ml}$ of water, and $1.7 \mathrm{~g}$ of agar). Cultures were incubated at $25^{\circ} \mathrm{C}$ for 4 days in light; then, cubes $(5$ $\mathrm{mm}$ ) were cut and placed in another sterile plate, semi-immersed in sterile water, and incubated for 7 days at $25^{\circ} \mathrm{C}$. Once sporangia formed, cultures were maintained for $30 \mathrm{~min}$ at $6^{\circ} \mathrm{C}$ to stimulate zoospore release. Plants were inoculated with a 15 $\mathrm{ml}$ suspension of 1 to $8.5 \times 10^{4}$ zoospores/ml, which was poured on the surface of saturated soil. The soil was kept saturated for $24 \mathrm{~h}$ and plants were maintained in a screenhouse with temperatures of 10 to $25^{\circ} \mathrm{C}$. Severity of disease symptoms, fresh weight of foliage and roots, and dry weight of roots were recorded after 7 days as described above.

Crown and root inoculation assays were designed as two separate, completely randomized experiments with four replicates using one plant as the experimental unit. Data were subjected to analysis of variance and means were separated according to Duncan-Waller $k$-ratio $t$ tests $(P<0.05)$ using the Multstat program (27).

A second pathogenicity test was conducted using tomato (Lycopersicon esculentum, cv. Yonit) and bell pepper (Capsicum frutescens cv. Bolga) obtained in a local nursery. Two-month-old plants were root inoculated with a $10^{6}$ propagules $/ \mathrm{ml}$ (including mycelium) suspension at 10 $\mathrm{ml} /$ plant prepared as described above. An equal number of noninoculated plants, injured and maintained in saturated soil, 
served as control. All inoculated and control plants were given soil-saturated treatments for $60 \mathrm{~min}$ followed by incubation in a growth chamber for 14 days at $25^{\circ} \mathrm{C}$ (58 to $63 \%$ relative humidity with $14 \mathrm{~h}$ of light and $10 \mathrm{~h}$ of darkness) before estimating aerial symptom severity as described above. Analysis of variance was performed for a completely randomized design with four replicates, and means were separated according to Duncan-Waller $k$-ratio $t$ tests $(P<0.05)$ using the Multstat program (27). This experiment was repeated once.

The ability of the pathogen to infect potato (Solanum tuberosum) tubers, and the fruit of avocado (Persea americana), bell pepper ( $C$. frutescens), cherry tomato, $(L$. esculentum), cucumber (Cucumis sativus), kiwifruit (Actinidia deliciosa), lemon (Citrus limon), pear (Pyrus communis), and pepino ( $S$. muricatum) was tested. Mature fruit and tubers of uniform color and size were selected, washed in running tap water, and surface disinfested for $60 \mathrm{~s}$ in $75 \%$ ethanol. Fruit and tubers were inoculated with a $0.5-\mathrm{ml}$ mycelial suspension $\left(10^{6}\right.$ propagules $/ \mathrm{ml}$ ) delivered in a 5-mmdiameter hole aseptically made with a cork borer. All isolates were tested on pepper fruit and potato tubers but only isolates $\mathrm{Ph}$ 2 and Ph- 3 were tested on fruit of the above-mentioned hosts. An equal number of injured, noninoculated fruit and tubers served as controls. Fruit and tubers were incubated in humid chambers at $20^{\circ} \mathrm{C}$ for 7 days before determining the diameter of the necrotic lesions that developed. Analysis of variance was performed separately for each fruit and potato tuber according to a completely randomized design with four replicates, and means were separated according to Duncan-Waller $k$-ratio $t$ tests $(P$ $<0.05)$ using the Multstat program (27).

At the end of each pathogenicity test, small segments of disease tissues were plated on PARPH for reisolation of the pathogen.

Effect of flooding stress. To study the effect of flooding stress, 70 10-week-old, white, grandiflora petunia plants (Petunia $\times$ hybrida, cv. Bravo F1) obtained in local nursery were used. Fifty plants were in- oculated with a mycelial suspension $\left(10^{6}\right.$ propagule $/ \mathrm{ml}$ ) of $P$. cryptogea, isolate $\mathrm{Ph}-3$, at $25 \mathrm{ml} /$ plant. The inoculum was obtained from CJB after 7 days of incubation at $20^{\circ} \mathrm{C}$. Mycelial mats were macerated in a blender using sterile distilled water. Inoculated and noninoculated plants were subjected to soil saturation for $12,24,48$, or $96 \mathrm{~h}$, keeping each plant wet with a continuous water column above the soil surface. After flooding, plants were drained and returned to a normal irrigation regime. An equal number of nonflooded but inoculated plants and noninoculated, nonflooded plants served as controls. All plants were kept for 20 days in a screenhouse with maximum air temperature ranging from 21 to $30^{\circ} \mathrm{C}$. The effect of flooding was evaluated using the 0-to-5 scale described above. Treatments were distributed at random in a two-by-five factorial design (inoculation by flooding period) with four replicates, using five plants as experimental unit. Results were analyzed for variance and means were separated according to the pairwise multiple comparison test of Tukey
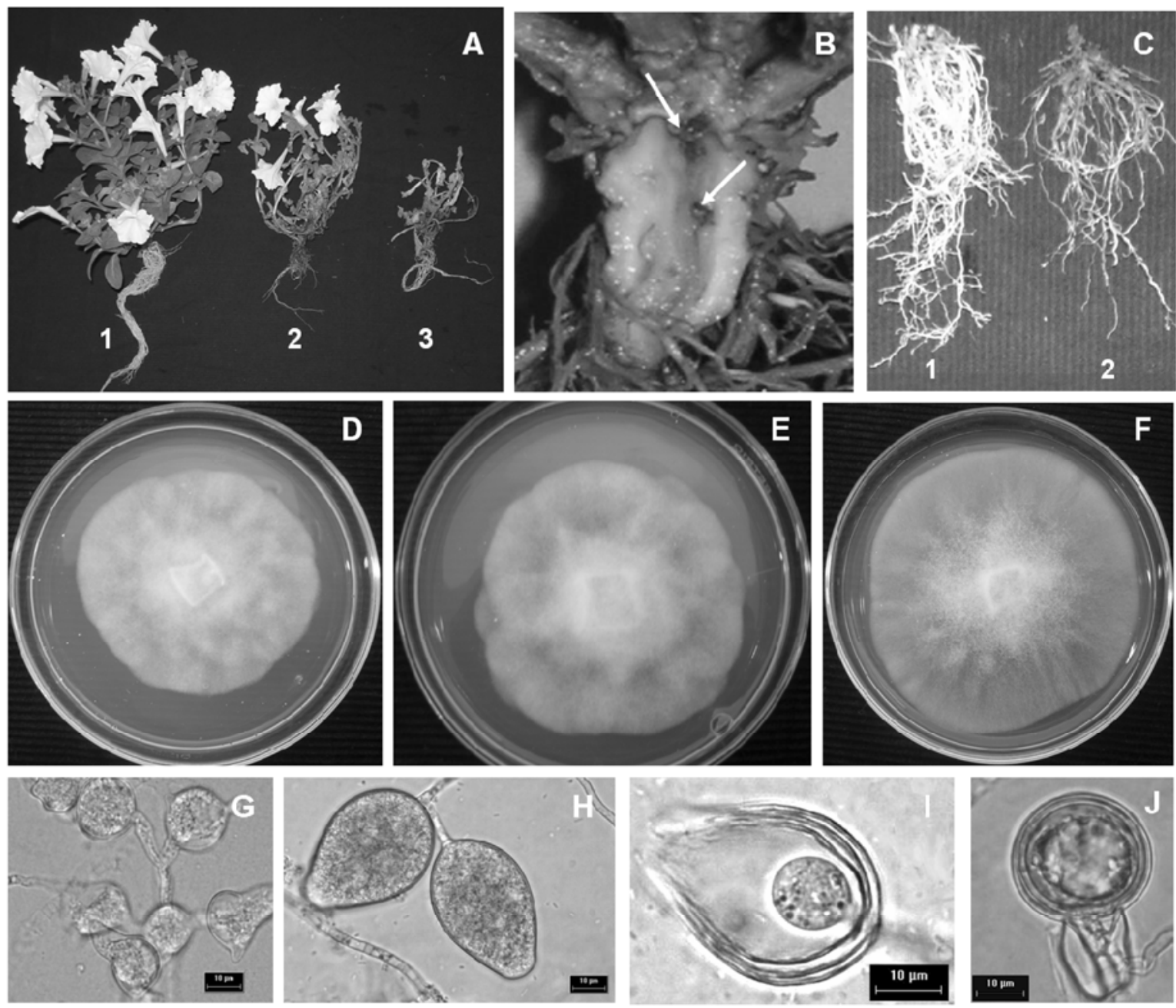

Fig. 1. Rapid decline of white grandiflora Petunia $\times$ hybrida caused by Phytophthora cryptogea. A, Pathogenicity test using mycelium as inoculum: 1 , healthy control plant; 2 and 3, diseased plants after inoculation with P. cryptogea isolates $\mathrm{Ph}-3$ and $\mathrm{Ph}-5$, respectively. B, Necrotic lesion development at the crown (arrows). C, Healthy noninoculated roots (1) and partially necrotic roots (2) inoculated with zoospores of $P$. cryptogea isolate Ph-3. D-F, Colony morphology of isolates of P. cryptogea obtained from petunia on V8-juice agar medium. D, Rosaceous (Ph-3); E, petalloid (Ph-2); and F, stellate (Ph-4). G, Rounded and irregular hyphal swellings. H, Ovoid to obpyriform sporangia. I, Internal proliferations of the sporangia. J, Amphigynous antheridium. 
$(P<0.05)$ (SigmaStat 2.0 program; SPSS Inc., Chicago). The relationship between flooding and root rot severity was adjusted to a polynomial model based on the significance of the coefficient of determination $\left(R^{2}\right)$. This experiment was repeated using red grandiflora petunia cv. Bravo F1 plants that were purchased as described above.

Efficacy of fungicides. The efficacy of the following fungicides was studied: (i) mefenoxam at $0.1 \mathrm{mg} / \mathrm{ml}+$ mancozeb at $1.6 \mathrm{mg} / \mathrm{ml}$ (Ridomil Gold MZ $68 \mathrm{WP}$; Syngenta), (ii) mefenoxam at $0.1 \mathrm{mg} / \mathrm{ml}+$ chlorothalonil at $1.0 \mathrm{mg} / \mathrm{ml}$ (Folio Gold $440 \mathrm{SC}$; Syngenta), (iii) mancozeb at 1.4 $\mathrm{mg} / \mathrm{ml}$ (Dithane, $80 \mathrm{WP}$; Agrícola Nacional Sociedad Agrícola Comercial e Industrial, Chile), and (iv) chlorothalonil at Roots of 32 plants were inoculated with 25 $\mathrm{ml}$ of a mycelial suspension with $10^{6}$ propagules $/ \mathrm{ml}$, prepared as previously $1.1 \mathrm{mg} / \mathrm{ml}$ (Bravo 720 EC; Syngenta).

described. An equal number of control plants were left untreated. All plants were flooded for $12 \mathrm{~h}$ following inoculation and maintained for 20 days in a screenhouse with maximum temperatures ranging from 14 to $26^{\circ} \mathrm{C}$. Fungicides were applied $36 \mathrm{~h}$ after inoculation as foliar sprays which were applied to run-off (approximately 45 $\mathrm{ml} /$ plant) or as soil drenches of approximately $100 \mathrm{ml} /$ plant. Ten-week-old white grandiflora petunia plants grown as described above were used. Treatments were distributed as a completely randomized design, with a two-by-four factorial structure with two application methods and four fungicide treatments (including nontreated controls), replicated four times. These results were subjected to a two-way analysis of variance (SigmaStat) and means were separated according to the pairwise multiple comparison test of Tukey $(P<0.05)$. This experiment was repeated.

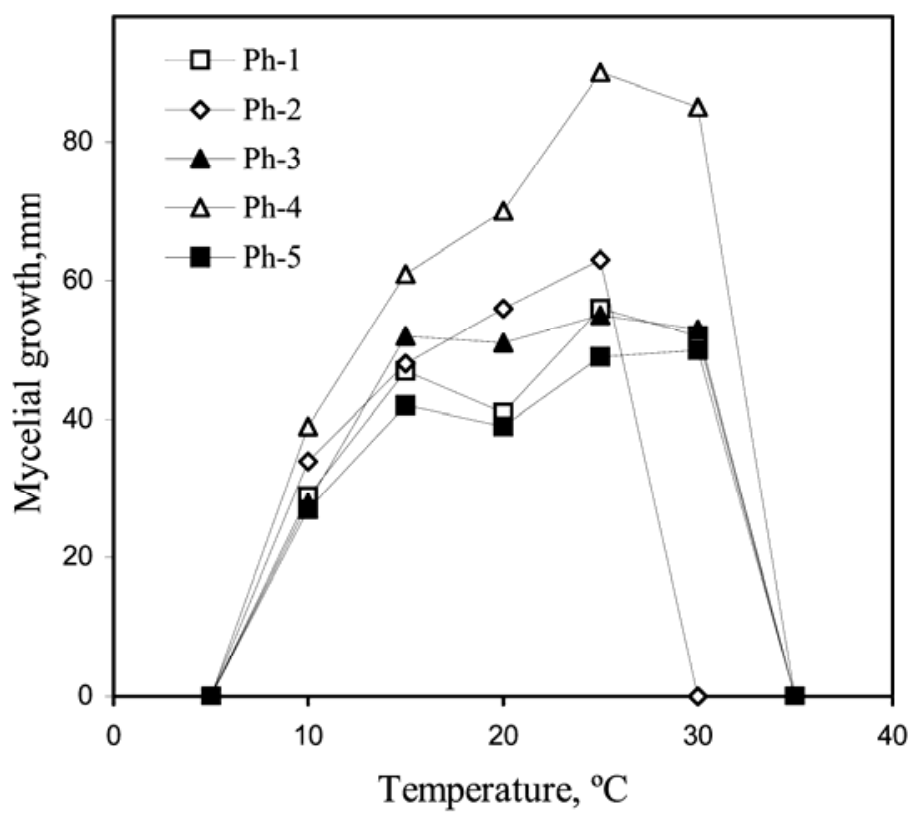

Fig. 2. Effect of temperature on growth of mycelium from isolates $\mathrm{Ph}-1, \mathrm{Ph}-2, \mathrm{Ph}-3, \mathrm{Ph}-4$, and $\mathrm{Ph}-5$ of Phytophthora cryptogea from petunia on amended corn meal agar after 7 days.

Table 1. Sexual compatibility among isolates of Phytophthora cryptogea infecting petunia (Petunia $\times$ hybrida) in Chile

\begin{tabular}{|c|c|c|c|c|c|c|}
\hline \multirow[b]{4}{*}{$P$. cryptogea isolates } & \multirow[b]{4}{*}{ Self-crossing } & \multicolumn{5}{|c|}{ Compatibility types ${ }^{y}$} \\
\hline & & \multicolumn{4}{|c|}{ P. cinnamomi } & \multirow{3}{*}{$\begin{array}{c}\text { P. cryptogea } \\
\mathrm{A1}^{\mathrm{z}} \\
\mathrm{MC}\end{array}$} \\
\hline & & \multicolumn{2}{|c|}{ A1 } & \multicolumn{2}{|c|}{ A2 } & \\
\hline & & MC & NMC & MC & NMC & \\
\hline $\mathrm{Ph}-1$ & - & + & - & - & - & + \\
\hline $\mathrm{Ph}-2$ & - & + & + & - & - & + \\
\hline $\mathrm{Ph}-3$ & - & + & + & - & - & + \\
\hline $\mathrm{Ph}-4$ & - & - & - & + & + & - \\
\hline $\mathrm{Ph}-5$ & - & + & - & - & - & + \\
\hline
\end{tabular}

y Oospores were present (+) or absent (-) on amended V8 juice agar (AV8) after 20 days of incubation in the dark. Cultures were separated by placing a sterile, $0.2-\mu \mathrm{m}$ nitrocellulose membrane between the tested isolates and each compatibility type. $\mathrm{MC}=$ direct mycelial contact between $P$. cinnamomi compatibility types and each $P$. cryptogea isolate and $\mathrm{NMC}=$ no mycelial contact between compatibility types and $P$. cryptogea isolates.

${ }^{\text {z }}$ Compatibility type A1 was $P$. cryptogea isolate $\mathrm{Ph}-4$.

\section{RESULTS}

Isolation and identification. Colonies of Phytophthora spp. were consistently obtained on APDA and PARPH from all 30 symptomatic petunia plants collected in five public parks from Santiago between November and December 2004. Similarly, all 10 diseased plants collected in 2005 also yielded Phytophthora spp. All isolates produced hyaline, coenocytic hyphae, branching at right angles, and persistent ovoid to obpyriform nonpapillate sporangia, and developed irregular, round, angular hyphal swellings mainly in CJB (Fig. 1). These characteristics are typical for group VI Phytophthora spp. as described by others $(8,26)$.

Five isolates were chosen for further study. These five isolates grew between 10 and $25^{\circ} \mathrm{C}$, with optimum between 20 and $25^{\circ} \mathrm{C}$. No mycelial growth was obtained at 5 and $35^{\circ} \mathrm{C}$ but four of five isolates grew at $30^{\circ} \mathrm{C}$ (Fig. 2). They had white stellate (isolate $\mathrm{Ph}-4$ ), petalloid (isolate $\mathrm{Ph}-2$ ), and rosaceous (isolates $\mathrm{Ph}-1, \mathrm{Ph}-3$, and $\mathrm{Ph}-5$ ) colony morphology on V8 juice agar medium (Fig. 1). Sporangia of isolate $\mathrm{Ph}-3$ were nonpapillate, persistent, and ovoid to obpyriform sporangia in liquid media (Fig. 1). Sporangia were $40.9 \pm 2.3$ by $27.5 \pm$ $3.9 \mu \mathrm{m}$, with a $1.5 \pm 0.03$ length:breadth ratio, produced terminally or on sympodially branching sporangiophores. Internal and external proliferations of the sporangiophores were produced (Fig. 1). No chlamydospores were observed.

P. cryptogea isolates $\mathrm{Ph}-1, \mathrm{Ph}-2, \mathrm{Ph}-3$, and $\mathrm{Ph}-5$ produced oospores when paired with $P$. cinnamomi compatibility type A1, and $P$. cryptogea isolate $\mathrm{Ph}-4$ formed oospores with $P$. cinnamomi compatibility type A2. Similarly, $\mathrm{Ph}-1, \mathrm{Ph}-2, \mathrm{Ph}-3$, and Ph-5 formed oospores when paired with $\mathrm{Ph}-4$ (Table 1): the oogonia were spherical to subspherical $(35.6 \pm 3.0$ by $34.9 \pm 3.4$ $\mu \mathrm{m})$, oospores were spherical, mainly plerotic, and smooth walled $(29.9 \pm 3.0$ by $29.2 \pm 3.2 \mu \mathrm{m})$, and antheridia were amphigynous and cylindrical, $15.0 \pm 1.7$ by $12.3 \pm 2.1 \mu \mathrm{m}$ (Fig. 1). Oospores formed by $\mathrm{Ph}-2, \mathrm{Ph}-3$, and $\mathrm{Ph}-4$ in membraneseparated crosses with $P$. cinnamomi were $29.8 \pm 3.8$ to $32.2 \pm 2.3 \mu \mathrm{m}$ in diameter. In addition, without mycelial contact, isolates $\mathrm{Ph}-2$ and $\mathrm{Ph}-3$ induced oospore production in isolates of $P$. cinnamomi compatibility type A1, and Ph-4 induced oospores in A2 (Table 1).

The electrophoretic pattern of PCR product digests performed with isolates Ph-3 and Ph-5 were identical to one another and different from those obtained for $P$. capsici, $P$. inundata, and $P$. fragariae var. fragariae (Fig. 3). These patterns were compared with those of CABI Bioscience isolates and were similar to those described for $P$. cryptogea. According to the PCR analysis, isolate Ph-3 (IMI 393160) had a 98 to $99 \%$ similarity with $P$. cryptogea type isolates (GenBank accession 
number EF093534) and was different from P. drechsleri.

Pathogenicity tests. All petunia plants developed moderate chlorosis, leaf lesions, and wilting when inoculated with $P$. cryptogea isolate $\mathrm{Ph}-3$. These foliage symptoms were always associated with root rot and a considerable reduction of the root mass, root weight, and foliage weight (Fig. 1 ). Independently of the type of inoculum used, extensive light-brown cankers that eventually girdled the crown were obtained (Tables 2 and 3). First symptoms consisted of leaf wilting and appeared after 4 to 5 days on noninjured plants that were soil inoculated using zoospores of isolates $\mathrm{Ph}-3$ and $\mathrm{Ph}-4$. After 14 days of incubation, 1 of $20(5 \%)$ and 5 of $20(25 \%)$ plants died following root and crown inoculation, respectively, using mycelial fragments. Based on the foliar and root symptoms, significant $(P<0.01)$ differences in sever-

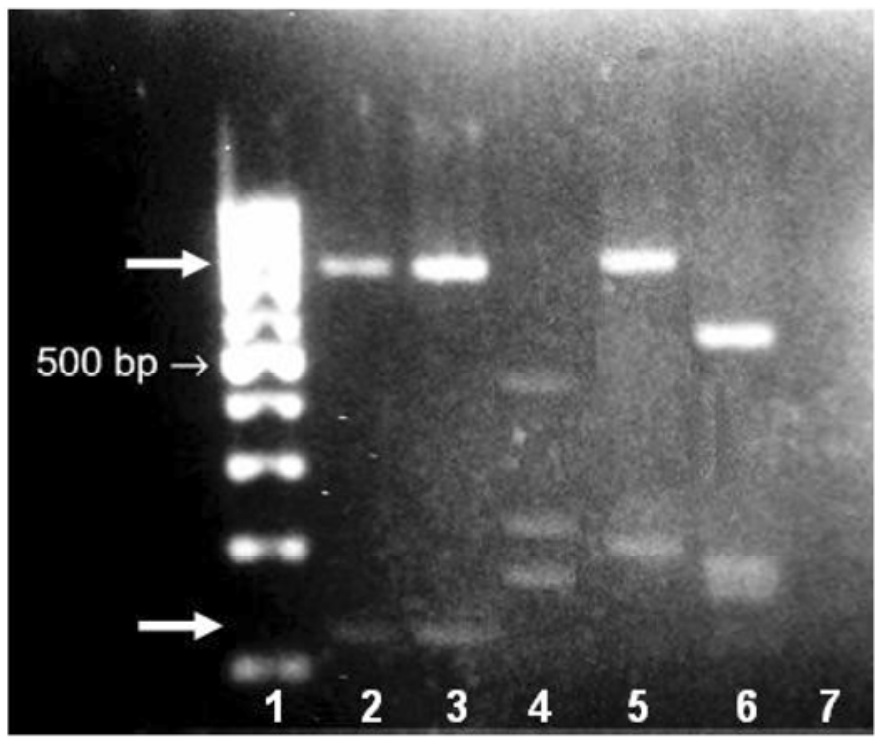

Fig. 3. Digest profiles obtained on the polymerase chain reaction (PCR) products of Phytophthora cryptogea recovered from petunia (Petunia $\times$ hybrida) for ITS4 and ITS6 primers and two restriction enzymes, AluI and MspI. Lane 1, standard marker; lane 2, Phytophthora cryptogea $\mathrm{Ph}-3$; lane 3, Ph-5; lane $4, P$. inundata; lane 5, P. fragariae var. fragariae; lane $6, P$. capsici; and lane 7 , negative control (water). PCR products of $P$. cryptogea isolates are indicated with large arrows. ity were found with different $P$. cryptogea isolates, with $\mathrm{Ph}-3$ and $\mathrm{Ph}-5$ causing the most severe disease. For instance, root fresh weight was reduced to 71 and $84 \%$, with a mean root rot index of 4.3 , when plants were root inoculated with isolates $\mathrm{Ph}-3$ and $\mathrm{Ph}-5$, respectively, whereas there was only a $43 \%$ reduction for isolate $\mathrm{Ph}-1$ (Table 2). The organisms reisolated from pathogenicity tests were confirmed as $P$. cryptogea by microscopic examination.

Four isolates were significantly pathogenic on petunia; however, only isolates $\mathrm{Ph}-1$ and $\mathrm{Ph}-5$ were significantly pathogenic on bell pepper and only isolate $\mathrm{Ph}-1$ was significantly pathogenic on tomato (Fig. 4). P. cryptogea was reisolated from samples selected from affected roots tissues and identification was confirmed microscopically.

All P. cryptogea isolates, except Ph-1, decayed potato tubers, causing necrotic lesions 13.2 to $41.5 \mathrm{~mm}$ in diameter. Diseased tissue turned pink after being exposed to air for 10 to $15 \mathrm{~min}$. All isolates caused a light-brown soft rot on bell pepper after 7 days of incubation. In another experiment, isolates $\mathrm{Ph}-2$ and $\mathrm{Ph}-3$ were pathogenic on fruit of avocado, cherry tomato, cucumber, kiwifruit, lemon, pear, and pepino, causing light-brown soft rot decay after 7 days of incubation (Table 4). $P$. cryptogea was reisolated from samples selected from affected potato tubers and the various fruit. Identification was confirmed as described above.

Effect of flooding stress. Soil saturation affected root rot development on white

Table 2. Pathogenicity and relative virulence of five isolates of Phytophthora cryptogea recovered from petunia (Petunia $\times$ hybrida) in public parks in Santiago, Chile

\begin{tabular}{|c|c|c|c|c|c|}
\hline \multirow[b]{3}{*}{ P. cryptogea isolates ${ }^{\mathrm{y}}$} & \multicolumn{5}{|c|}{ Pathogenicity $^{x}$} \\
\hline & \multicolumn{3}{|c|}{ Root symptoms } & \multicolumn{2}{|c|}{ Foliar symptoms } \\
\hline & Fresh weight (mg) & Dried weight (mg) & Severity $^{\mathrm{z}}$ & Fresh weight (g) & Severity $^{z}$ \\
\hline \multicolumn{6}{|l|}{ Root inoculations } \\
\hline Ph-1 & $625 \mathrm{bc}$ & $160 a b$ & $2.5 \mathrm{bc}$ & $3.6 \mathrm{ab}$ & $3.5 \mathrm{e}$ \\
\hline $\mathrm{Ph}-2$ & $425 \mathrm{ab}$ & $143 \mathrm{ab}$ & $2.8 \mathrm{c}$ & $9.2 \mathrm{ab}$ & $2.0 \mathrm{~cd}$ \\
\hline $\mathrm{Ph}-3$ & $325 \mathrm{ab}$ & $118 \mathrm{ab}$ & $4.3 \mathrm{~d}$ & $2.5 \mathrm{a}$ & $4.2 \mathrm{e}$ \\
\hline $\mathrm{Ph}-4$ & $500 \mathrm{bc}$ & $183 \mathrm{bc}$ & $3.0 \mathrm{c}$ & $9.0 \mathrm{ab}$ & $1.0 \mathrm{bc}$ \\
\hline $\mathrm{Ph}-5$ & $175 \mathrm{a}$ & $70 \mathrm{a}$ & $4.3 \mathrm{~d}$ & $2.5 \mathrm{a}$ & $3.7 \mathrm{e}$ \\
\hline \multicolumn{6}{|l|}{ Flooded controls } \\
\hline Injured, noninoculated & $750 \mathrm{bc}$ & $203 \mathrm{bc}$ & $1.5 \mathrm{~b}$ & $7.6 \mathrm{ab}$ & $1.3 \mathrm{bc}$ \\
\hline Noninjured, noninoculated & $625 \mathrm{bc}$ & $218 \mathrm{bc}$ & $1.5 \mathrm{~b}$ & $7.0 \mathrm{ab}$ & $0.5 \mathrm{ab}$ \\
\hline \multicolumn{6}{|l|}{ Nonflooded controls } \\
\hline Noninjured, noninoculated & $1,100 \mathrm{c}$ & $350 \mathrm{c}$ & $0.3 \mathrm{a}$ & $15.4 \mathrm{~b}$ & $0.0 \mathrm{a}$ \\
\hline \multicolumn{6}{|l|}{ Crown inoculations } \\
\hline $\mathrm{Ph}-1$ & $480 \mathrm{ab}$ & $210(\mathrm{~ns})$ & $2.0 \mathrm{bc}$ & $3.4 \mathrm{ab}$ & $4.5 \mathrm{c}$ \\
\hline $\mathrm{Ph}-2$ & $400 \mathrm{ab}$ & 210 & $3.0 \mathrm{~cd}$ & $2.6 \mathrm{a}$ & $3.5 \mathrm{bc}$ \\
\hline $\mathrm{Ph}-3$ & $250 \mathrm{a}$ & 140 & $4.5 \mathrm{e}$ & $2.6 \mathrm{a}$ & $4.5 \mathrm{c}$ \\
\hline $\mathrm{Ph}-4$ & $400 \mathrm{ab}$ & 180 & $2.3 \mathrm{c}$ & $3.5 \mathrm{ab}$ & $2.3 \mathrm{~b}$ \\
\hline $\mathrm{Ph}-5$ & $280 \mathrm{a}$ & 160 & $4.3 \mathrm{de}$ & $3.4 \mathrm{ab}$ & $3.5 \mathrm{bc}$ \\
\hline Injured, noninoculated & $750 \mathrm{~b}$ & 260 & $1.0 \mathrm{ab}$ & $3.6 \mathrm{ab}$ & $0.0 \mathrm{a}$ \\
\hline Noninjured, noninoculated & $625 \mathrm{~b}$ & 220 & $0.5 \mathrm{a}$ & $4.1 \mathrm{~b}$ & $0.0 \mathrm{a}$ \\
\hline
\end{tabular}

${ }^{\mathrm{x}}$ Means of four replicates within a column followed by a common letter are not significantly different according to Duncan-Waller $k$-ratio $t$ tests $(P=0.05)$ Percent severities were angular transformed before analysis but untransformed severity mean indexes are presented; ns $=$ not significant for analysis of variance. Fresh weights were determined on air-dried roots and foliage, and dried root weight was determined after $24 \mathrm{~h}$ at $60^{\circ} \mathrm{C}$.

${ }^{y}$ Root inoculations were performed with $25 \mathrm{ml}$ of a $10^{6}$ propagules $/ \mathrm{ml}$ mycelial suspension delivered to the roots in one location. Crown inoculations were done with a $9-\mathrm{mm}^{2}$ mycelium plug that was inserted underneath the bark.

${ }^{\mathrm{z}}$ Severity was visually estimated on a 0 -to- 5 scale, where $0=$ healthy roots or foliage and $1,2,3,4$, and 5 were $<20,21-40,41-60,61-80$, and $>80 \%$, respectively, of rotted roots or foliage showing wilting, chlorosis, leaf necrosis, and stunt. 
Grandiflora petunia. Root rot increased significantly $(P \leq 0.05)$ as flooding periods increased from 0 to $96 \mathrm{~h}$. Flooding periods above $48 \mathrm{~h}$ resulted in considerable root damage on both inoculated and noninoculated plants and it was difficult to separate the possible negative effect due to flooding alone. A polynomial model best explained the relationship between soil saturation period $(X)$ and root rot $(Y)$ in both inoculated $\left(Y=-0.0005 X^{2}+0.07 X+1.73, R^{2}=\right.$ $0.83)$ and noninoculated $\left(Y=0.0003 X^{2}+\right.$ $\left.0.07 X+0.5, R^{2}=0.92\right)$ plants (Fig. 5). Similarly, $Y=0.0003 X^{2}+0.03 X+3.9, R^{2}$ $=0.50$ and $Y=0.00004 X^{2}+0.02 X+0.72$, $R^{2}=0.73$ for inoculated and noninoculated red grandiflora petunia, respectively (data not shown).

Efficacy of fungicides. A highly significant $(P<0.001)$ fungicide effect was obtained in experiments 1 and 2 with treatments where there was reduction in the root rot index and an increase in the root and foliage fresh weight. The best fungicide effect was obtained with mefenoxam at $1.4 \mathrm{mg} / \mathrm{ml}$ mixed with mancozeb at $1.6 \mathrm{mg} / \mathrm{ml}$ or chlorothalonil at $1.0 \mathrm{mg} / \mathrm{ml}$. Mancozeb and chlorothalonil alone, at the rates of 1.4 and $1.1 \mathrm{mg} / \mathrm{ml}$, respectively, had little or no control effect. The effect of the application method and the interaction between soil drench applications and foliage spray were not statistically significant (Table $5)$.

Table 3. Pathogenicity of Phytophthora cryptogea on petunia (Petunia $\times$ hybrida) inoculated with zoospores from isolates $\mathrm{Ph}-3$ and $\mathrm{Ph}-4^{\mathrm{x}}$

\begin{tabular}{lccccc}
\hline & \multicolumn{2}{c}{ Foliage $^{\mathbf{y}}$} & & \multicolumn{2}{c}{ Root weight (mg) $^{\text {P. cryptogea } \text { isolates }}$} \\
\cline { 2 - 3 } \cline { 5 - 6 } & Wilting (\%) & Fresh weight $(\mathbf{g})$ & & Fresh & Dry $^{\mathbf{z}}$ \\
\hline Ph-3 & $17 \mathrm{a}$ & $14.8 \mathrm{a}$ & & $400 \mathrm{a}$ & $85.5 \mathrm{a}$ \\
$\mathrm{Ph}-4$ & $25 \mathrm{~b}$ & $12.8 \mathrm{a}$ & & $700 \mathrm{a}$ & $88.7 \mathrm{a}$ \\
Noninoculated & $0 \mathrm{c}$ & $24.2 \mathrm{~b}$ & & $1,700 \mathrm{~b}$ & $205.1 \mathrm{~b}$ \\
\hline
\end{tabular}

${ }^{\mathrm{x}}$ Means of five replicates within a column followed by a common letter are not significantly different according to Duncan-Waller $k$-ratio $t$ tests $(P=0.05)$.

${ }^{y}$ Percent wilting was recorded 7 days after inoculation using a 0 -to- 5 scale, where $0=$ healthy plants and $1,2,3,4$, and 5 were $<20,21-40,41-60,61-80$, and $>80 \%$, respectively, of the foliage was wilted. Plants were inoculated with a zoospore suspension at $15 \mathrm{ml} /$ plant adjusted to 1 to $8.5 \times 10^{4}$ zoospores $/ \mathrm{ml}$.

${ }^{\mathrm{z}}$ Roots were dried for $24 \mathrm{~h}$ at $60^{\circ} \mathrm{C}$. indicate that oospore formation was induced by hormones or chemical stimulants as reported for other Phytophthora spp. $(11,14)$.

Isolates of $P$. cryptogea were pathogenic on white and red grandiflora petunia, re-
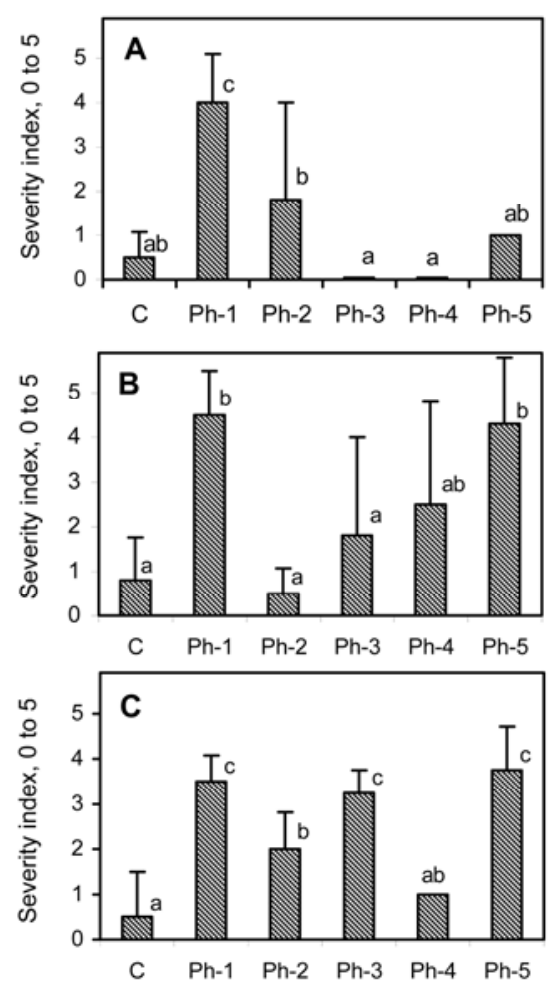

Fig. 4. Pathogenicity of Phytophthora cryptogea isolates $\mathrm{Ph}-1,-2-3,-4$, and -5 from petunia (Petunia $\times$ hybrida), determined as severity of root symptoms in a 0 -to-5 scale, where $0=$ healthy roots and 1, 2, 3, 4, and 5 were $<20,21-$ $40,41-60,61-80$, and $>80 \%$, respectively, of rotted roots. A, Tomato cv. Yonit. B, Bell pepper cv. Bolga. C, White grandiflora petunia. The bars represent the means ( \pm standard error) of four replicates with five plants per isolate or treatment. Bars with the same letter were not statistically different according to DuncanWaller $k$-ratio $t$ test $(P=0.05)$. Percent severities were angular transformed $[\arcsin (\operatorname{sqrt}(\mathrm{x}))]$ before analysis but untransformed severity mean indexes are presented. $\mathrm{C}=$ Flooded but noninoculated controls.

Table 4. Pathogenicity of Phytophthora cryptogea on various fruit and potato tubers

\begin{tabular}{|c|c|c|c|c|c|c|c|c|c|}
\hline \multirow[b]{4}{*}{$P$. cryptogea isolates } & \multicolumn{9}{|c|}{ Diameter of the necrotic lesion developed $(\mathrm{mm})^{\mathrm{z}}$} \\
\hline & \multirow{2}{*}{\multicolumn{2}{|c|}{$\begin{array}{c}\text { Experiment } 1 \\
\text { Solanaceous }\end{array}$}} & \multicolumn{7}{|c|}{ Experiment 2} \\
\hline & & & \multicolumn{2}{|c|}{ Solanaceous } & \multicolumn{5}{|c|}{ Others } \\
\hline & Bell pepper & Potato & Cherry tomato & Pepino & Avocado & Cucumber & Kiwi & Lemon & Pear \\
\hline $\mathrm{Ph}-1$ & $9.8 \mathrm{~b}$ & $0.0 \mathrm{a}$ & $\mathrm{nt}$ & $\mathrm{nt}$ & $\mathrm{nt}$ & $\mathrm{nt}$ & $\mathrm{nt}$ & $\mathrm{nt}$ & nt \\
\hline $\mathrm{Ph}-2$ & $12.6 \mathrm{~b}$ & $33.0 \mathrm{bc}$ & $22.2 \mathrm{~b}$ & $54.0 \mathrm{~b}$ & $35.0 \mathrm{~b}$ & $49.5 \mathrm{c}$ & $36.7 \mathrm{~b}$ & $37.0 \mathrm{~b}$ & $21.4 \mathrm{~b}$ \\
\hline $\mathrm{Ph}-3$ & $23.6 \mathrm{c}$ & $41.5 \mathrm{c}$ & $29.5 \mathrm{c}$ & $55.5 \mathrm{~b}$ & $24.8 \mathrm{~b}$ & $37.3 \mathrm{~b}$ & $36.8 \mathrm{~b}$ & $35.0 \mathrm{~b}$ & $37.3 \mathrm{c}$ \\
\hline $\mathrm{Ph}-4$ & $32.6 \mathrm{~d}$ & $13.2 \mathrm{~b}$ & nt & nt & nt & nt & nt & nt & nt \\
\hline Ph-5 & $17.3 \mathrm{bc}$ & $27.8 \mathrm{bc}$ & $\mathrm{nt}$ & nt & nt & $\mathrm{nt}$ & nt & $\mathrm{nt}$ & nt \\
\hline Noninoculated & $0.0 \mathrm{a}$ & $0.0 \mathrm{a}$ & $0.0 \mathrm{a}$ & $0.0 \mathrm{a}$ & $0.0 \mathrm{a}$ & $0.0 \mathrm{a}$ & $0.0 \mathrm{a}$ & $0.0 \mathrm{a}$ & $0.0 \mathrm{a}$ \\
\hline
\end{tabular}

${ }^{\mathrm{z}}$ Disease evaluated 7 days post inoculation. Bell pepper (Capsicum frutescens var. grossum) fruit and potato (Solanum tuberosum) tubers were inoculated with a mycelial plug aseptically inserted. Fruit of avocado (Persea americana), cherry tomato (Lycopersicon esculentum), cucumber (Cucumis sativus), kiwifruit (Actinidia deliciosa), lemon (Citrus limon), pear (Pyrus communis), and pepino (S. muricatum) were wound inoculated with a $10^{6} \mathrm{propagule} / \mathrm{ml}$ mycelial suspension. Means of four replicates followed within a column followed by a common letter are not significantly different according to DuncanWaller $k$-ratio $t$ tests $(P=0.05)$; $\mathrm{nt}=$ not tested. 
producing the symptoms observed in naturally infected plants after crown and root inoculations with mycelium fragments and after soil inoculations with zoospores. Foliar symptoms appeared on noninjured plants 4 to 5 days after soil inoculation with zoospores, suggesting that these $P$. cryptogea isolates were very aggressive. Presumably, zoospores may directly penetrate root or crown tissue under field con- ditions. However, only injured plants developed symptoms when mycelial fragments were used as inoculum. Noninjured but inoculated plants remained healthy (data not shown).

Symptoms were similar to those described for diseases caused by this pathogen in other ornamental species (6) and include wilt, moderate leaf chlorosis, necrosis, stunt, root rot, and light-brown

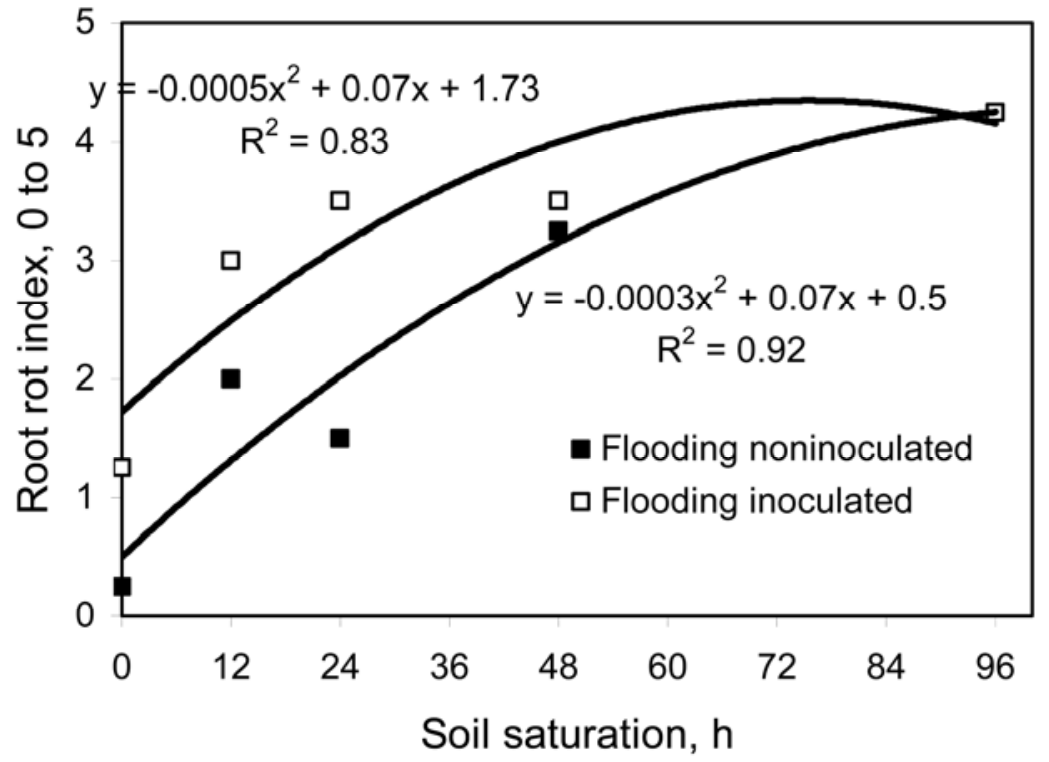

Fig. 5. Relationship between soil saturation period and root rot of petunia caused by Phytophthora cryptogea. Root rot was estimated by the mass of rotten roots where $0=100 \%$ healthy roots and 1,2 , 3,4 , and 5 were $<20,21-40,41-60,61-80$, and $>81 \%$ root rot, respectively. Each point represents the mean of four replicates with five plants per replicate. canker on the crown. Unlike the late blight caused by $P$. infestans, crown canker and root rot were invariably present. Additionally, P. cryptogea was never isolated from aerial tissues or found naturally sporulating on leaf or stems as one would expect for $P$. infestans (7). Reisolations made from inoculated petunia always yielded $P$. cryptogea, successfully fulfilling Koch's postulates. Reisolations from all other treatments were unsuccessful; therefore, the lower fresh weight obtained on flooding controls was attributed mainly to the negative effect of the flooding episodes themselves (Table 2; Fig. 4).

Some differences in virulence were observed among isolates, with $\mathrm{Ph}-5$ causing more disease than others. It was interesting that the severity index range of foliar symptoms, after mycelial inoculations, was less than 20 to more than $61 \%$ for $\mathrm{Ph}-4$ and $\mathrm{Ph}-3$, respectively, after mycelial inoculations. However, these same isolates were equally virulent after zoospore inoculations, reinforcing the potential importance of zoospores as the likely primary inoculum under field conditions. Some isolates of P. cryptogea were also pathogenic to other solanaceous and nonsolanaceous host plants. These preliminary tests demonstrate that $P$. cryptogea isolates recovered from petunia in Chile are not restricted to petunia. The pathogen of petunia appears to exhibit a wide host range, at least for fruit infections. A wide host range has been described for most populations of $P$. cryptogea worldwide (8).

Table 5. Effect of fungicide treatments applied as foliage spray or as a soil drench to 10 -week-old white grandiflora petunia $($ Petunia $\times$ hybrida $)$ on root rot and foliage fresh weight after inoculation with Phytophthora cryptogea ${ }^{w}$

\begin{tabular}{|c|c|c|c|c|c|}
\hline \multicolumn{2}{|l|}{ Fungicide treatments ${ }^{x}$} & \multicolumn{2}{|c|}{ Experiment $1^{y}$} & \multicolumn{2}{|c|}{ Experiment $2^{y}$} \\
\hline Active ingredients & Rate (mg a.i./ml) & Soil drench & Foliage spray & Soil drench & Foliage spray \\
\hline \multicolumn{6}{|l|}{ Root rot index $(0 \text { to } 5)^{\mathrm{z}}$} \\
\hline Mancozeb & 1.4 & $3.5 \mathrm{a}$ & $3.3 \mathrm{a}$ & $2.8 \mathrm{a}$ & $3.3 \mathrm{a}$ \\
\hline Mefenoxam + mancozeb & $0.1+1.6$ & $1.5 \mathrm{~b}$ & $0.3 \mathrm{~b}$ & $0.0 \mathrm{~b}$ & $0.0 \mathrm{~b}$ \\
\hline Mefenoxam + chlorothalonil & $0.1+1.0$ & $0.8 \mathrm{~b}$ & $1.3 \mathrm{~b}$ & $0.5 \mathrm{~b}$ & $0.5 \mathrm{~b}$ \\
\hline Chlorothalonil & 1.1 & nt & nt & $3.8 \mathrm{a}$ & $3.8 \mathrm{a}$ \\
\hline Untreated controls & nt & $2.8 \mathrm{a}$ & $2.0 \mathrm{a}$ & $2.3 \mathrm{a}$ & $4.8 \mathrm{a}$ \\
\hline Mean & $\ldots$ & 6.5 & 1.7 & 2.4 & 3.1 \\
\hline \multicolumn{6}{|l|}{ Root fresh weight (mg) } \\
\hline Mancozeb & 1.4 & $780 \mathrm{~b}$ & $930 \mathrm{~b}$ & $900 \mathrm{~b}$ & $910 \mathrm{~b}$ \\
\hline Mefenoxam + mancozeb & $0.1+1.6$ & $1,080 a b$ & $1,300 \mathrm{a}$ & $1,760 \mathrm{a}$ & $2,070 \mathrm{a}$ \\
\hline Mefenoxam + chlorothalonil & $0.1+1.0$ & $1,730 \mathrm{a}$ & $1,300 \mathrm{a}$ & $2,310 \mathrm{a}$ & $1,400 \mathrm{a}$ \\
\hline Chlorothalonil & 1.1 & $\mathrm{nt}$ & nt & $530 \mathrm{~b}$ & $800 \mathrm{~b}$ \\
\hline Untreated controls & $\ldots$ & $300 \mathrm{~b}$ & $780 \mathrm{~b}$ & $1,150 \mathrm{~b}$ & $550 \mathrm{~b}$ \\
\hline Mean & $\ldots$ & 970 & 1,080 & 1,330 & 1,140 \\
\hline \multicolumn{6}{|l|}{ Foliage fresh weight $(\mathrm{g})$} \\
\hline Mancozeb & 1.4 & $13.4 \mathrm{a}$ & $12.3 \mathrm{~b}$ & 10.4 & $6.7 \mathrm{~b}$ \\
\hline Mefenoxam + mancozeb & $0.1+1.6$ & $25.6 \mathrm{a}$ & $37.1 \mathrm{a}$ & 38.6 & $36.3 \mathrm{a}$ \\
\hline Mefenoxam + chlorothalonil & $0.1+1.0$ & $39.4 \mathrm{a}$ & $31.6 \mathrm{a}$ & 32.5 & $27.2 \mathrm{a}$ \\
\hline Chlorothalonil & 1.1 & nt & nt & 6.5 & $11.2 \mathrm{~b}$ \\
\hline Untreated controls & nt & $5.2 \mathrm{~b}$ & $14.8 \mathrm{~b}$ & 6.8 & $9.9 \mathrm{~b}$ \\
\hline Mean & $\ldots$ & 20.9 & 24.0 & 18.9 & 18.2 \\
\hline
\end{tabular}

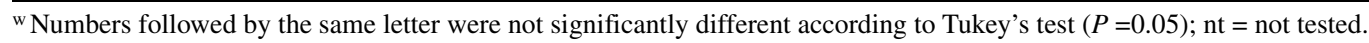

x Fungicides were applied as soil drench or as a foliage spray using 100 or $45 \mathrm{ml} / \mathrm{plant}$, respectively. Formulated fungicides were: chlorothalonil (Bravo 720 EC; Syngenta, Chile), mefenoxam + mancozeb (Ridomil Gold MZ 68 WP; Syngenta), mefenoxam + chlorothalonil (Folio Gold 440 SC; Syngenta), and mancozeb (Dithane, $80 \mathrm{WP}$; Agrícola Nacional Sociedad .Agrícola Comercial e Industrial, Chile).

y A significant $(P<0.003)$ fungicide $(\mathrm{F})$ effect was obtained but the application method $(\mathrm{AM})$ and the interaction between $\mathrm{F}$ and $\mathrm{AM}$ were nonsignificant.

${ }^{\mathrm{z}}$ Level of root rot was obtained using a visual estimation based on a $0-5$ scale where $0=100 \%$ healthy roots and $1,2,3,4$, and 5 were $<20 \%, 21-40 \%, 41-$ $60 \%, 61-80 \%$, and $>80 \%$ rotted roots, respectively. 
Disease symptoms were obtained in the absence of a soil saturation episode. However, similar to other studies $(1,2,4,8,15$, $21,23,30)$, the severity of the symptoms obtained considerably increased as the length of the flooding episode increased from 0 to $96 \mathrm{~h}$ of flooding. Therefore, the frequent and excessive irrigation regime normally used to water petunia in nurseries and in public parks is probably conducive to the development of this disease. Furthermore, the presence of diseased plants observed in noninoculated soil could be attributed to natural inoculum present in plants obtained from commercial nurseries. P. cryptogea was isolated from these noninoculated control plants, although less frequently than isolations from inoculated plants.

The efficacy of mefenoxam at 0.1 $\mathrm{mg} / \mathrm{ml}$ mixed with either chlorothalonil at $1.0 \mathrm{mg} / \mathrm{ml}$ or mancozeb at $1.6 \mathrm{mg} / \mathrm{ml}$ to control P. cryptogea was demonstrated in these studies. Mefenoxam, the most active enantiomer highly specific for the control of oomycetes, replaced metalaxyl late in the $1990 \mathrm{~s}(12,22,24)$. In the work presented here, the best control was obtained with mefenoxam, because chlorothalonil and mancozeb alone, at the rate used, proved to be ineffective against $P$. cryptogea. Although potted petunia plants were treated $36 \mathrm{~h}$ after inoculation with $P$. cryptogea, foliar spray and soil drench applications were equally effective in arresting the development of the rapid decline of petunia caused by $P$. cryptogea .

This study demonstrated that P. cryptogea is the cause of the rapid decline found on petunia in Santiago, Chile. To our knowledge, this is a first report describing a disease caused by $P$. cryptogea on petunia. The biology and ecology of $P$. cryptogea in petunia and other ornamental plants must be further investigated.

\section{ACKNOWLEDGMENTS}

We thank J. T. Matus, Pontificia Universidad Católica de Chile, for his assistance during this investigation.

\section{LITERATURE CITED}

1. Besoain, X., Arenas, C. Salgado, E., and Latorre B. A. 2005. Effect of the flooding period on the development of avocado (Persea ameri- cana) root rot caused by Phytophthora cinnamomi. Cien. Inv. Agr. (Chile, online) 32:79-84.

2. Blaker N. S., and MacDonald, J. D. 1981. Predisposing effects of soil moisture extremes on the susceptibility of rhododendron to Phytophthora root and crown rot. Phytopathology 71:831-834.

3. Boersma, J. G., Cooke, D. E. L., and Sivasithamparam, K. 2000. A survey of wildflower farms in the South-West of Western Australia for Phytophthora spp. associated with root rots. Aust. J. Exp. Agric. 40:1011-1019.

4. Bowers, J. H., and Mitchell, D .J. 1990. Effect of soil-water potential and periodic flooding on mortality of pepper caused by Phytophthora capsici. Phytopathology 80:14471450.

5. Cooke, D. E. L., Drencht, A., Duncan, J. M. Wagels, G., and Brasier, C. M. 2000. A molecular phylogeny of Phytophthora and related Oomycetes. Fungal Genet. Biol. 30:17-32.

6. Daughtrey M. L., Wick, R. L., and Peterson, J. L. 1995. Compendium of Flowering Potted Plant Diseases. The American Phytopathological Society, St. Paul, MN

7. Deahl, K. L., and Fravel, D. R. 2003. Occurrence of leaf blight on petunia caused by Phytophthora infestans in Maryland. Plant Dis. 87:1004.

8. Erwin, D. C., and Ribeiro, O. K. 1996. Phytophthora Diseases Worldwide. The American Phytopathological Society, St. Paul MN.

9. Ferguson, A. J., and Jeffers, S. N. 1999. Detecting multiple species of Phytophthora in container mixes from ornamental crop nurseries. Plant Dis. 83:1129-1136.

10. Guzmán, G., Latorre, B. A, and. Wilcox, W. F. 2005. First report of Phytophthora cryptogea root and crown rot on peach trees in Chile. Plant Dis. 89:1010.

11. Ho, H.-H., and Jong, S. C. 1986. A comparison between Phytophthora cryptogea and P. drechleri. Mycotaxon 27:289-319.

12. Hwang, J., and Benson, D. M. 2005. Identification, mefenoxam sensitivity, and compatibility type of Phytophthora spp. attacking floriculture crops in North Carolina. Plant Dis. 89:185-190.

13. Jeffers, S. N., and Martin, S. B. 1986. Comparison of two media selective for Phytophthora and Pythium species. Plant Dis. 70:1038-1043.

14. Ko,W.-H. 1988. Hormonal heterothallism and homothallism in Phytophthora. Annu. Rev. Phytopathol. 26:57-73.

15. Kuan, T. L., and Erwin, D. C. 1980. Predisposition effect of water saturation of soil on Phytophthora root rot of alfalfa. Phytopathology 70:981-986.

16. Lamour, K. H., Daughtrey, M. L., Benson, D. M., Hwang, J., and , M. K. 2003. Etiology of Phytophthora drechsleri and $P$. nicotianae $(=P$. parasitica) diseases affecting floriculture crops. Plant Dis. 87:854-858.
17. Latorre, B. A., Alvarez, C., and Ribeiro, O. K. 1991. Phytophthora root rot of kiwifruit in Chile. Plant Dis. 75:949-952.

18. Latorre, B. A., Pérez, G., Wilcox, W. F., and Torres, R. 1995. Comparative protein electrophoretic and isoenzymic patterns of Phytophthora cryptogea isolates from Chilean kiwifruit and North American deciduous fruits. Plant Dis. 79:703-708.

19. Latorre, B. A., Rioja, M. E., and Wilcox, W. F. 2001. Phytophthora species associated with crown and root rot of apple in Chile. Plant Dis. 85:603-606.

20. Latorre, B. A., Wilcox, W. F., and Bañados, M. P. 1997. Crown and root rots of table grapes caused by Phytophthora spp. in Chile. Vitis 36:195-197.

21. MacDonald, J. D., and Duniway, J. M. 1978. Temperature and water stress effects on sporangium viability and zoospore discharge in Phytophthora cryptogea and P. megasperma. Phytopathology 68:1449-1455.

22. Matheron, M. E. 2002. Comparative ability of six fungicides to inhibit development of Phytophthora gummosis on citrus. Plant Dis. 86:687-690.

23. Matheron, M. E., and S. M. Mircetich. 1985 Influence of flooding duration on development of Phytophthora root and crown rot of Juglans hindsii and Paradoux walnut rootstocks. Phytopathology 75:973-976.

24. Matheron, M. E., and Porchas, M. 2000. Comparison of five fungicides on development of root, crown, and fruit rot of chile pepper and recovery of Phytophthora capsici from soil. Plant Dis. 84:1038-1043.

25. Mills, S., Förster, H., and Coffey, M. D. 1991. Taxonomic structure of Phytophthora cryptogea and P. drechsleri based on isozyme and mitochondrial DNA analyses. Mycol. Res. 95:31-48.

26. Newhook. J, Waterhouse, G., and Stamps, D. 1978. Tabular key to the species of Phytophthora de Bary. Mycol. Pap. 143. Commonwealth Mycological Institute Kew, Surrey, England.

27. Shane, W. W., and Joyner, J. G. 1990. Applical, Randoma and Multstat the microcomputer utilities for managing field trial experiments. Plant Dis. 74:333-334.

28. Stamps, D. J. 1978. Phytophthora cryptogea. Descriptions of pathogenic fungi and bacteria Mycol. Pap. 592. Commonwealth Mycological Institute, Kew, England.

29. Wilcox, W. F., and B. A. Latorre. 2002. Identities and geographic distributions of Phytophthora spp. causing root rot of red raspberry in Chile. Plant Dis. 86:13571362.

30. Wilcox, W. F., and Mircetich, S. M. 1985. Influence of soil water matric potential on the development of Phytophthora root and crown rots of Mahaleb Cherry. Phytopathology 75:649-653. 